NBER WORKING PAPER SERIES

GENETIC DIVERSITY AND THE ORIGINS OF CULTURAL FRAGMENTATION

Quamrul Ashraf

Oded Galor

Working Paper 18738

http://www.nber.org/papers/w18738

\author{
NATIONAL BUREAU OF ECONOMIC RESEARCH \\ 1050 Massachusetts Avenue \\ Cambridge, MA 02138 \\ January 2013
}

The authors are grateful to Stelios Michalopoulos for helpful comments. Daniel Prinz provided able research assistance. Ashraf's research is supported by a Hellman Fellowship from Williams College. Galor's research is supported by the National Science Foundation (SES-0921573) and the Population Studies and Training Center (PSTC) at Brown University. The PSTC receives core support from the Eunice Kennedy Shriver National Institute of Child Health and Human Development (5R24HD041020). The views expressed herein are those of the authors and do not necessarily reflect the views of the National Bureau of Economic Research.

NBER working papers are circulated for discussion and comment purposes. They have not been peerreviewed or been subject to the review by the NBER Board of Directors that accompanies official NBER publications.

(C) 2013 by Quamrul Ashraf and Oded Galor. All rights reserved. Short sections of text, not to exceed two paragraphs, may be quoted without explicit permission provided that full credit, including $₫$ notice, is given to the source. 
Genetic Diversity and the Origins of Cultural Fragmentation

Quamrul Ashraf and Oded Galor

NBER Working Paper No. 18738

January 2013

JEL No. N30,O10,O50,Z10

\begin{abstract}
$\underline{\text { ABSTRACT }}$
Despite the importance attributed to the effects of diversity on the stability and prosperity of nations, the origins of the uneven distribution of ethnic and cultural fragmentation across countries have been underexplored. Building on the role of deeply-rooted biogeographical forces in comparative development, this research empirically demonstrates that genetic diversity, predominantly determined during the prehistoric "out of Africa" migration of humans, is an underlying cause of various existing manifestations of ethnolinguistic heterogeneity. Further exploration of this uncharted territory may revolutionize the understanding of the effects of deeply-rooted factors on economic development and the composition of human capital across the globe.
\end{abstract}

Quamrul Ashraf

Williams College

Department of Economics

24 Hopkins Hall Drive

Williamstown, MA 01267

Quamrul.H.Ashraf@williams.edu

Oded Galor

Department of Economics

Brown University

Box B

Providence, RI 02912

and NBER

oded_galor@brown.edu 
Diversity has emerged as a fundamental force in the stability and prosperity of nations. The intensities of fractionalization and polarization across ethnic, linguistic, and religious groups have been associated with economic growth, the quality of governance, the provision of public goods, the prevalence of civil conflict, and endogenous nation formation. ${ }^{1}$ Nevertheless, the origins of the uneven distribution of ethnic and cultural fragmentation across countries have been largely neglected. ${ }^{2}$

An emerging body of evidence suggests that deeply-rooted factors, determined tens of thousands of years ago, have significantly affected the level of diversity and the course of comparative economic development from the dawn of human civilization to the contemporary era. ${ }^{3}$ In particular, Ashraf and Galor (2013) advance and empirically establish the hypothesis that, in the course of the prehistoric exodus of Homo sapiens out of Africa, migratory distance to various indigenous settlements across the globe adversely affected the level of genetic diversity, and thereby generated a persistent hump-shaped effect on development outcomes, reflecting the tradeoff between the beneficial and detrimental effects of diversity on productivity.

Building upon the insight of the biogeographical roots of comparative development, this paper explores an underlying unity in the origins of the various forms of ethnic and cultural fragmentation in contemporary national populations. It advances the hypothesis that genetic diversity, determined predominantly during the migration of humans out of Africa tens of thousands of years ago, is a fundamental determinant of observed ethnic and cultural heterogeneity, as reflected by the number of ethnic groups and the levels of ethnolinguistic fractionalization and polarization within modern national boundaries.

Following the "out of Africa" migration, the initial level of genetic diversity in indigenous settlements presumably facilitated the formation of distinct ethnic groups through a process of endogenous group selection, based on the tradeoff between the costs and benefits associated with heterogeneity and scale. ${ }^{4}$ While heterogeneity raised the likelihood of disarray and mistrust, reducing cooperation and thus adversely affecting group-specific productivity, complementarities across diverse productive traits and preferences stimulated productivity. Since in a given environment, diminishing marginal returns to diversity and homogeneity entail an optimal size for each group, higher initial genetic diversity would have positively contributed to the number of groups, and thus to the degree of fractionalization. Further, to the extent that higher initial diversity did not lead to an excessively large number of groups, it would have positively contributed to the degree of polarization as well. ${ }^{5}$

Consistent with the proposed hypothesis, this research establishes that genetic diversity is an underlying cause of a broad spectrum of existing manifestations of ethnic and cultural diversity. Exploiting migratory distance from East Africa as an exogenous source of cross-country variation in contemporary genetic diversity, the empirical analysis demonstrates that genetic diversity has signifi-

\footnotetext{
${ }^{1}$ For an overview, see Alesina and La Ferrara (2005).

${ }^{2}$ Recent exceptions are studies on the effects of geographical variability (Michalopoulos, 2012) and the duration of human settlement (Ahlerup and Olsson, 2012) on linguistic diversity.

${ }^{3}$ See Spolaore and Wacziarg (forthcoming) for a survey.

${ }^{4}$ Over time, as the forces of cultural drift augmented intergroup divergences in language, customs, and norms, thereby reinforcing the barriers to intergroup assimilation, distinct ethnic identities were formed.

${ }^{5}$ If local geographical factors complemented a specific spectrum of productive traits and preferences, genetic diversity, coupled with spatial variability in geographical factors, may have facilitated the sorting of the regional population into spatially segregated communities, and thus the effect of genetic diversity on the degree of fractionalization or polarization could potentially be nonmonotonic.
} 
cant positive effects on the number of ethnic groups and the levels of ethnolinguistic fractionalization and polarization, conditional on a comprehensive set of potentially confounding geographical and historical factors.

\section{Estimation Strategy}

The empirical analysis examines the average reduced-form effects of genetic diversity on a wide range of measures of contemporary ethnolinguistic heterogeneity at the country level, including (i) the log number of ethnic groups (EG), compiled by Fearon (2003); (ii) two distinct measures of ethnic fractionalization (EF-F and EF-A), constructed by Fearon (2003) and Alesina et al. (2003), respectively; (iii) indices of ethnolinguistic fractionalization (ELF-D) and polarization (POL-D), based on deeply-rooted ancestral cleavages among linguistic groups in the population (i.e., level 1), developed by Desmet, Ortuño-Ortín and Wacziarg (2012); and (iv) measures of ethnolinguistic polarization, based on the methodologies of Esteban-Ray (POL-ER) and Reynal-Querol (POL-RQ), constructed by Esteban, Mayoral and Ray (2012).

Given that cross-country migrations in the post-1500 era significantly affected the distribution of genetic and cultural diversity, especially across countries in the New World, the measure of contemporary genetic diversity developed by Ashraf and Galor (2013) is employed as the main independent variable. However, since this measure may be spuriously correlated with the component of contemporary ethnolinguistic diversity that was shaped by the forces of colonialism and globalization over the past 500 years, two distinct identification strategies are utilized. First, the analysis focuses on a subsample comprised exclusively of countries in the Old World, thereby eliminating the potentially confounding role of mass migrations from the Old World in contributing to both genetic and ethnolinguistic diversity in New-World populations over the past half millennium. Second, the analysis employs migratory distance from East Africa as an instrument for contemporary genetic diversity in a global sample of countries, exploiting the highly significant negative first-stage relationship between genetic diversity and migratory distance from the cradle of humankind. ${ }^{6}$

The analysis also accounts for a large vector of geographical covariates. Specifically, in light of the hypothesis of Michalopoulos (2012) that geographical variability, as reflected by variations in regional land quality and elevation, contributed significantly to ethnolinguistic fractionalization, controls are introduced for the mean and the standard deviation of land quality and elevation as well as the dispersion in elevation within a country. ${ }^{7}$ Further, since ecological biodiversity decreases with distance from the equator, a spatial gradient that is also manifested by linguistic diversity, absolute latitude is included as a standard control. Moreover, to account for other geographicallydriven channels that may have shaped endogenous group formation, promoted spatial segregation, or reinforced intergroup differences through cultural drift and the accumulation of group-specific human

\footnotetext{
${ }^{6}$ As discussed by Ashraf and Galor (2013), this relationship reflects a serial founder effect of the "out of Africa" demic expansion process, whereby subgroups leaving their parental colonies to establish new settlements at greater distances from the cradle of humankind carried with them only a portion of the overall diversity of their parental colonies.

${ }^{7}$ The findings of Michalopoulos (2012) are consistent with the notion that heterogeneity in geographical factors hindered mobility among groups and gave rise to nontransferable location-specific human capital, thereby promoting the cultural drift of spatially segregated groups over time.
} 
capital, the analysis additionally controls for the percentage of arable land, distance to waterways, total land area, average monthly temperature and precipitation, the percentage of total land area in Köppen-Geiger tropical and subtropical climate zones, disease richness, and island and landlocked fixed effects.

In addition, the empirical analysis considers three historical forces that may have influenced ethnic diversity. First, the advent of sedentary agriculture may have contributed to both ethnic fissions and fusions. While the increase in social stratification spurred by the Neolithic Revolution may have catalyzed group formation, the rise of institutionalized statehood may have served to homogenize ethnic identities. Second, to the extent that new peripheral groups could have emerged over time, reflecting the inefficient provision of public goods from core groups, the duration of human settlement in a given location since prehistoric times could have contributed to ethnic diversity (Ahlerup and Olsson, 2012). Third, the distribution of contemporary ethnolinguistic diversity across countries partly reflects the legacy of colonialism, via the divide-and-rule strategies enacted by colonial powers, the imposition of colonial institutions designed to achieve stronger political influence by assimilating groups into larger units, and major cross-continental migrations associated with the colonial period. Hence, the analysis controls for the time elapsed since the Neolithic Revolution, the duration of human settlement since prehistory, and the duration of experience as a colony.

Finally, a complete set of continental fixed effects is included to account for the possibility that unobserved continent-specific geographical and historical characteristics may have codetermined the global distributions of genetic and ethnolinguistic diversity.

\section{Estimation Results}

The empirical results establish that genetic diversity is a fundamental determinant of ethnic and cultural fragmentation, as reflected by various forms of ethnolinguistic heterogeneity. Exploiting variations in a sample of 143 countries for which data on all employed variables are available, Column 1 of Table 1 presents the results from an OLS regression of the log number of ethnic groups on genetic diversity and the full set of geographical and historical controls. As depicted in panel (a) of Figure 1, genetic diversity has a highly statistically significant positive relationship with the log number of ethnic groups. In particular, a 10 percentage point increase in genetic diversity is associated with 1 additional ethnic group, relative to a baseline of 5.25 groups in the representative national population. ${ }^{8}$ Further, the partial $R^{2}$ associated with genetic diversity indicates that the residual variation in diversity explains 7 percent of the residual variation in the log number of ethnic groups.

Regarding the geographical covariates, consistent with Michalopoulos (2012), variation in land quality has a statistically significant positive relationship with ethnic diversity. In contrast, distance from the equator does not appear to be systematically related to the number of ethnic groups. The entire set of controls for geographical variability explain 4 percent of the residual variation in the log number of groups.

\footnotetext{
${ }^{8} \mathrm{~A} 10$ percentage point increase in genetic diversity can be interpreted as a 0.1 increase in the probability that two randomly-selected individuals in a population are genetically different from one another with respect to a given spectrum of traits.
} 


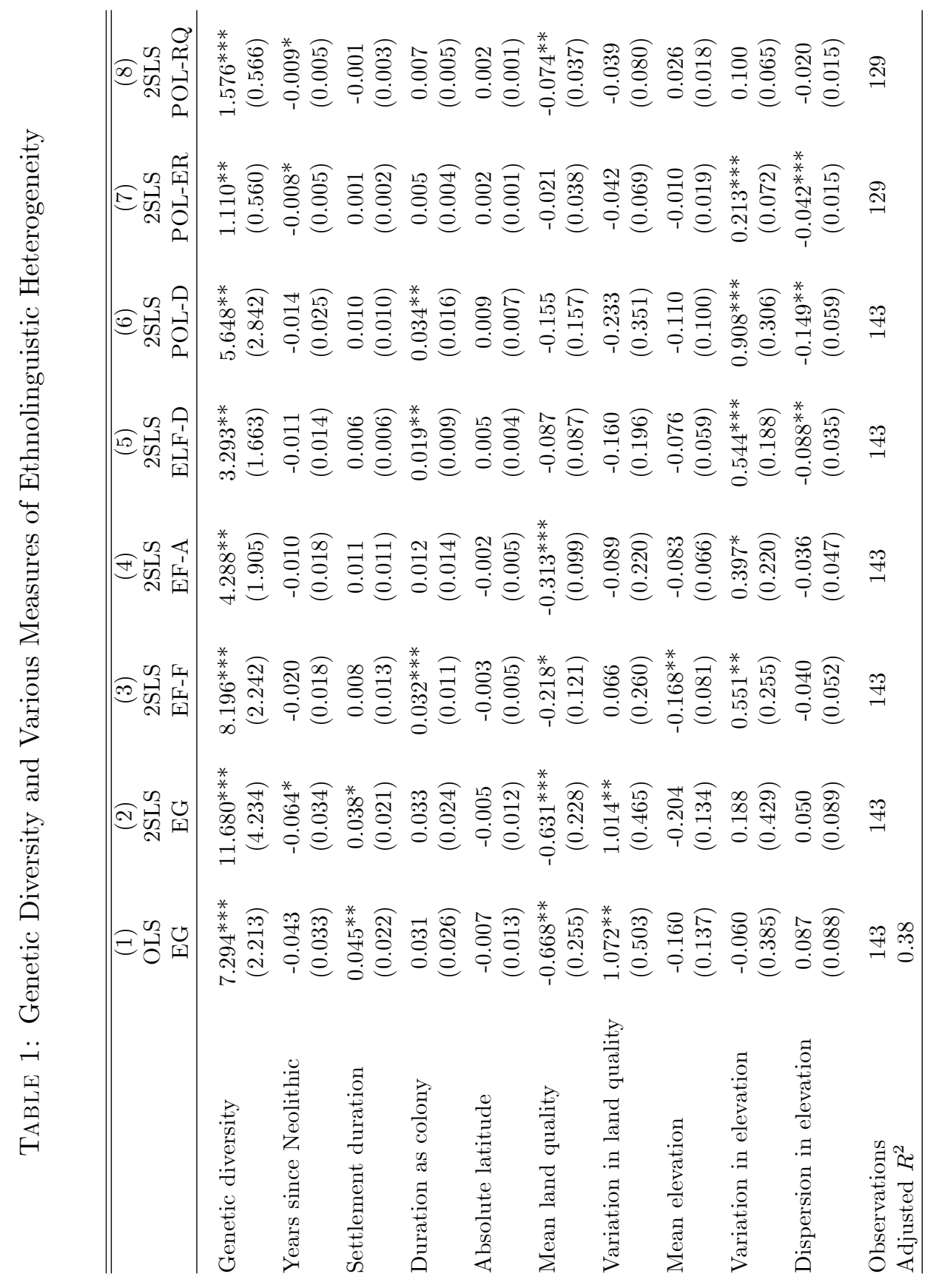

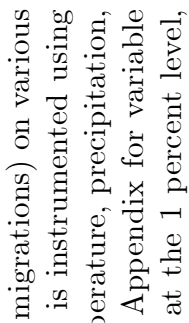

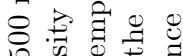

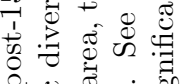

讨

记

要

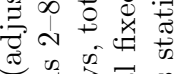

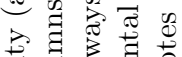

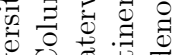

ह

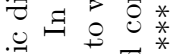

过 它

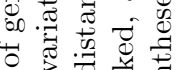

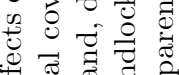

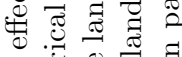

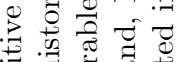

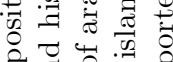

궁

范

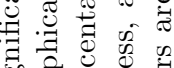

क

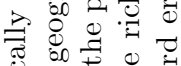

茟范范

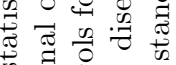

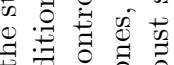

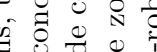

苛 ¿

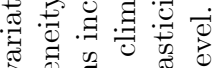

त.

०ै कु

की 50.040

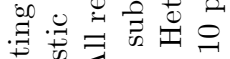

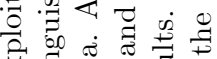

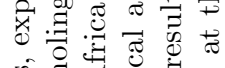

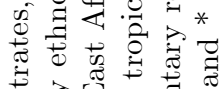

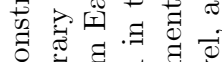

:

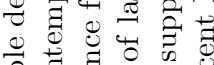

䒕

.

F

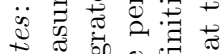

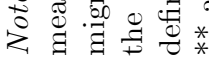


As for the historical controls, the negative (albeit insignificant) coefficient on the time elapsed since the Neolithic transition is consistent with a homogenizing role of early institutionalized statehood, while the positive (but insignificant) coefficient on the duration of colonial experience accords with divide-and-rule strategies enacted by colonialists on native populations. Moreover, the significant positive coefficient on the duration of human settlement is consistent with the notion that ethnic fissions emerge over time. These three historical forces together explain 6 percent of the residual variation in the log number of groups.

Reassuringly, the estimated impact of genetic diversity on the number of ethnic groups is stronger when one accounts for the potentially confounding role of mass migrations from the Old World to the New World over the last 500 years. In particular, as depicted in panel (b) of Figure 1, if the regression from Column 1 is performed on a subsample comprised exclusively of countries in the Old World, both the coefficient and the partial $R^{2}$ associated with genetic diversity become quantitatively larger, consistent with the hypothesis that genetic diversity primarily contributed to more ancient indigenous intergroup cleavages.

To further address the potential endogeneity between genetic and ethnic diversity due to globalization in the last half millennium, Column 2 estimates a 2SLS variant of the specification from Column 1, with genetic diversity instrumented by migratory distance from East Africa. The results indicate that the causal effect of genetic diversity on the log number of ethnic groups is quantitatively twice as strong as the OLS relationship from Column 1. Specifically, the 2SLS coefficient on genetic diversity implies that a 10 percentage point increase in genetic diversity increases the number of ethnic groups in the population by 2 .

The regressions in Columns 3 and 4 explore the explanatory power of exogenous variation in genetic diversity for the observed variation in measures of ethnic fractionalization across countries, based on Fearon (2003) and Alesina et al. (2003), respectively. ${ }^{9}$ Genetic diversity is found to have a highly statistically significant positive effect on ethnic fractionalization. The estimate in Column 3 suggests that a 10 percentage point increase in genetic diversity increases the degree of ethnic fractionalization by 8 percentage points. ${ }^{10}$

The next two columns investigate the influence of instrumented genetic diversity on linguistic heterogeneity, as reflected by fractionalization (Column 5) and polarization (Column 6) across linguistic groups within a country, categorized by Desmet, Ortuño-Ortín and Wacziarg (2012) based on ancestral cleavages among contemporary spoken languages. Genetic diversity confers a statistically significant positive effect on both measures, suggesting that it has indeed played a causal role in generating culturally fragmented populations in the distant past. ${ }^{11}$ Finally, the regressions

\footnotetext{
${ }^{9}$ Since the 2SLS method is superior (relative to focusing on a Old-World sample of countries) in terms of exploiting global variations, it is employed as the identification strategy in Columns 3-8. In addition, since endogeneity bias may be more severe in these columns, given the functional dependence of fractionalization and polarization indices on the distribution of the population across groups, the OLS estimates of the relationship with genetic diversity do not reveal a robust systematic pattern in the global as opposed to the Old-World sample.

${ }^{10}$ An 8 percentage point increase in ethnic fractionalization can be interpreted as a 0.08 increase in the probability that two randomly-selected individuals in a population belong to different ethnic groups.

${ }^{11}$ Ancestral linguistic cleavages are identified by the branches that are closest to the roots of country-specific hierarchical linguistic trees. More recent branches in such evolutionary trees, however, are overwhelmingly governed by processes of cultural drift and cultural admixture. As such, linguistic groups categorized according to these recent splits are less likely to reflect a prehistoric endogenous group formation process, where the initial domain of genetic diversity
} 

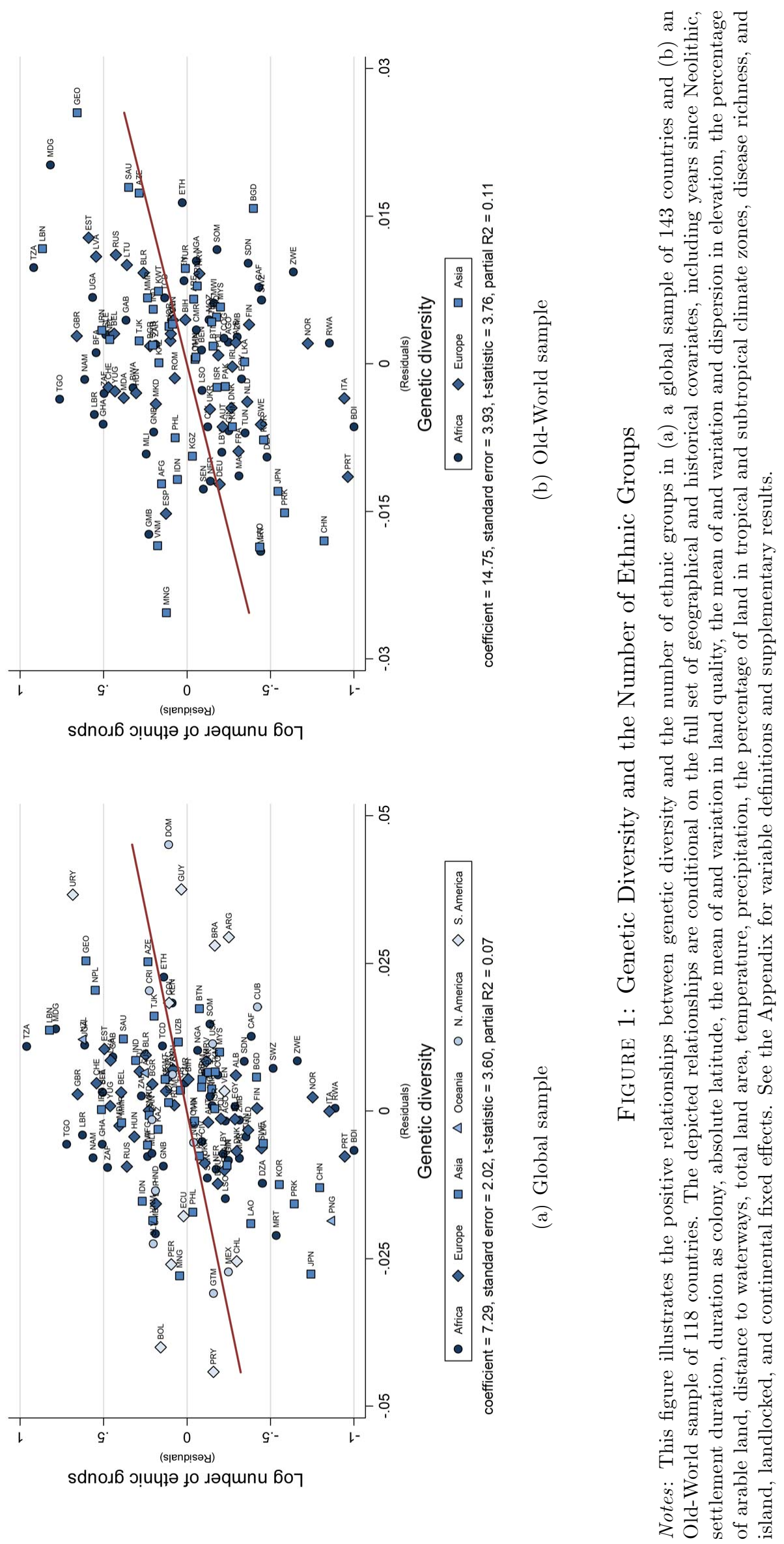
in Columns 7 and 8 examine the impact of exogenous variation in genetic diversity on observed variations in indices of ethnolinguistic polarization, showing that genetic diversity has significantly contributed to not only the degree of fractionalization but the extent of polarization as well.

\section{Concluding Remarks}

Despite the importance attributed to the role of diversity in the stability and prosperity of nations, the origins of the uneven distribution of ethnic and cultural heterogeneity across countries have been underexplored. This research establishes that genetic diversity is an underlying cause of a broad spectrum of existing manifestations of ethnic and cultural fragmentation. Further exploration of this largely uncharted territory may revolutionize the understanding of the process of economic development and the persistent effects that deeply-rooted factors have had on the composition of human capital and economic development across the globe, fostering the design of policies aimed at promoting growth and alleviating poverty.

may have played a fundamental role. Thus, genetic diversity and geographical variability do not possess significant explanatory power for measures of fractionalization and polarization across linguistic groups classified using modern language categories. 


\section{Appendix}

\section{A Variable Definitions and Sources}

\section{A.1 Dependent Variables}

Number of ethnic groups [EG]. The total number of distinct ethnic groups in a country's population, as compiled by Fearon (2003). The cross-country variable employed by the empirical analysis is the natural logarithm of one plus the number of ethnic groups. See Fearon (2003) for additional details on primary data sources and methodological assumptions.

Ethnic fractionalization [EF-F/EF-A]. The probability that 2 randomly-selected individuals in a country's population belong to different ethnic groups. Formally, the ethnic fractionalization index for each country is calculated as:

$$
F R A C=1-\sum_{i=1}^{n} p_{i}^{2},
$$

where $p_{i}$ is the proportional representation of ethnic group $i$ in the national population; and $n$ is the total number of ethnic groups comprising the country's population. Data on ethnic groups (and their proportional representations in the national population) by country are compiled independently by Alesina et al. (2003) and Fearon (2003), thus yielding two separate (but correlated) cross-country measures of ethnic fractionalization. See Alesina et al. (2003) and Fearon (2003) for additional details on primary data sources and methodological assumptions.

Ethnolinguistic fractionalization, level-1 aggregation [ELF-D]. An index of fractionalization, constructed by Desmet, Ortuño-Ortín and Wacziarg (2012), across the ancestral categories of the modern linguistic groups in a country's population. The ancestral linguistic divisions in a country's population correspond to the branches that are closest to the "root" of the country-specific phylogenetic linguistic tree. To compute the fractionalization index, the proportional representations (in the national population) of the modern linguistic groups are first aggregated up into different bins, each corresponding to one of these proto-language branches of the linguistic tree. For each country, the index is then calculated across these bins (or ancestral linguistic groups) by applying the same equation as the one underlying the calculation of the ethnic fractionalization index. See Desmet, Ortuño-Ortín and Wacziarg (2012) for additional details on primary data sources and methodological assumptions.

Ethnolinguistic polarization, level-1 aggregation [POL-D]. An index of polarization, constructed by Desmet, Ortuño-Ortín and Wacziarg (2012), across the ancestral categories of the modern linguistic groups in a country's population. The ancestral linguistic divisions in a country's population correspond to the branches that are closest to the "root" of the country-specific phylogenetic linguistic tree. To compute the polarization index, the proportional representations (in the national population) of the modern linguistic groups are first aggregated up into different bins, each corresponding to one of these proto-language branches of the linguistic tree. For each country, the index is then calculated across these bins (or ancestral linguistic groups) by applying the following 
definition of polarization due to Reynal-Querol (2002) and Montalvo and Reynal-Querol (2005):

$$
P O L=4 \sum_{i=1}^{n} p_{i}^{2}\left[1-p_{i}\right],
$$

where $p_{i}$ is the proportional representation of ancestral linguistic group $i$; and $n$ is the total number of ancestral linguistic groups. See Desmet, Ortuño-Ortín and Wacziarg (2012) for additional details on primary data sources and methodological assumptions.

Ethnolinguistic polarization, Esteban-Ray index [POL-ER]. An index of polarization, constructed by Esteban, Mayoral and Ray (2012), across the ethnic groups in a country's population, where ethnic groups by country are classified according to Fearon (2003) and the definition of polarization that is applied is the one due to Duclos, Esteban and Ray (2004) and Esteban and Ray (2011) that incorporates intergroup distances. Formally, the polarization index for each country is calculated as:

$$
P O L=\sum_{i=1}^{n} \sum_{j=1}^{n} p_{i}^{2} p_{j}\left[1-s_{i j}^{0.05}\right],
$$

where $p_{i}$ is the proportional representation of ethnic group $i$ in the national population; $n$ is the total number of ethnic groups comprising the country's population; and $s_{i j}$ is the "degree of similarity" between the languages spoken by ethnic groups $i$ and $j$, given by the ratio of the number of common branches (shared by the two languages) to the maximum possible number of branching steps (i.e., 15 ) in the phylogenetic linguistic tree for all languages worldwide. See Esteban, Mayoral and Ray (2012) for additional details on primary data sources and methodological assumptions.

Ethnolinguistic polarization, Reynal-Querol index [POL-RQ]. An index of polarization, constructed by Esteban, Mayoral and Ray (2012), across the ethnic groups in a country's population, where ethnic groups by country are classified according to Fearon (2003) and the definition of polarization that is applied is the one due to Reynal-Querol (2002) and Montalvo and Reynal-Querol (2005). See Esteban, Mayoral and Ray (2012) for additional details on primary data sources and methodological assumptions.

\section{A.2 Independent and Instrumental Variables}

Migratory distance from East Africa. The great circle distance from Addis Ababa, Ethiopia to a country's modern capital city along a land-restricted path forced through one or more of five aforementioned intercontinental waypoints, including Cairo, Egypt; Istanbul, Turkey; Phnom Penh, Cambodia; Anadyr, Russia; and Prince Rupert, Canada. Distances are calculated using the Haversine formula and are measured in units of a thousand kilometers. The methodology underlying the construction of this measure is adopted from Ramachandran et al. (2005). The geographical coordinates of the waypoints are obtained from Ramachandran et al. (2005) and those of the modern capital cities are obtained from the Central Intelligence Agency's (CIA) World Factbook online. See Ashraf and Galor (2013) for additional details.

Genetic diversity. The expected heterozygosity (genetic diversity) of a country's contemporary national population, as developed by Ashraf and Galor (2013). This measure is based on migratory 
distances from East Africa to the year 1500 locations of the ancestral populations of the country's component ethnic groups in 2000 and on the pairwise migratory distances among these ancestral populations. The source countries of the ancestral populations are identified from the World Migration Matrix, 1500-2000 (Putterman and Weil, 2010), and the modern capital cities of these countries are used to compute the aforementioned migratory distances. The measure of genetic diversity is then computed by applying (i) the coefficients obtained from regressing expected heterozygosity on migratory distance from East Africa at the ethnic group level, using a worldwide sample of 53 ethnic groups comprising the Human Genome Diversity Cell Line Panel, compiled by the Human Genome Diversity Project (HGDP) and the Centre d'Étude du Polymorphisme Humain (CEPH); (ii) the coefficients obtained from regressing pairwise genetic distance on pairwise migratory distance in a sample of 1,378 HGDP-CEPH ethnic group pairs, and (iii) the ancestry weights representing the fractions of the year 2000 national population (i.e., of the country for which the measure is being computed) that can trace their ancestral origins to different source countries in the year 1500 . The ethnic group (and group-pair) level data on expected heterozygosities, geographical coordinates, and pairwise genetic distances are obtained from Ramachandran et al. (2005), and the country level data on ancestry weights are obtained from the World Migration Matrix, 1500-2000 website. See Ashraf and Galor (2013) for a detailed discussion of the methodology underlying the construction of this measure.

Years since Neolithic. The number of thousand years elapsed (as of the year 2000) since the majority of the population residing within a country's modern national borders began practicing sedentary agriculture as the primary mode of subsistence. This measure, reported by Putterman (2008), is compiled using a wide variety of both region- and country-specific archaeological studies as well as more general encyclopedic works on the transition from hunting and gathering to agriculture during the Neolithic Revolution. See the Agricultural Transition Data Set website for additional details on primary data sources and methodological assumptions.

Settlement duration. The maximum duration, in tens of thousands of years, of uninterrupted settlement by anatomically modern humans across locations within a country's modern national borders, as reported by Ahlerup and Olsson (2012). See Ahlerup and Olsson (2012) for additional details on primary data sources and methodological assumptions.

Duration as colony. The duration, in centuries, of experience by a country (or any subregion thereof) as a colony of one or more colonial powers, including the United Kingdom, France, Spain, Portugal, the Netherlands, Belgium, Italy, Germany, and the United States. In cases where different regions within a country's modern national borders were simultaneously colonized by different colonial powers, the durations of experience as a colony is aggregated across these regions. This variable is constructed by the authors of the current paper, based on colonization and decolonization dates obtained from a wide range of online resources, including (but not limited to) the CIA's World Factbook, the Encyclopaedia Brittanica, and Country Studies of the Library of Congress. Additional details on primary data sources and methodological assumptions are available from the authors upon request. 
Absolute latitude. The absolute value of the latitude of a country's geodesic centroid, as reported on the Gothos website, based on online metadata from (i) the National Geospatial-Intelligence Agency's (NGA) GEOnet Names Server (GNS) and (ii) the United States Geological Survey's (USGS) Geographic Names Information System (GNIS).

Mean land quality. A geospatial index of the suitability of land for agriculture, based on ecological indicators of climate suitability for cultivation, such as growing degree days and the ratio of actual to potential evapotranspiration, as well as on ecological indicators of soil suitability for cultivation, such as soil carbon density and soil pH. This index was initially developed at a half-degree resolution by Ramankutty et al. (2002), and it has been aggregated up to the country level by Michalopoulos (2012), by averaging values across the grid cells that are located within a country's national borders. The variable employed by the current analysis is thus the aggregate measure reported by Michalopoulos (2012). See Michalopoulos (2012) for additional details.

Variation in land quality. The standard deviation of the agricultural suitability index (as discussed above) across the grid cells (at a half-degree resolution) that are located within a country's national borders, as reported by Michalopoulos (2012). See Michalopoulos (2012) for additional details.

Mean elevation. The average elevation of a country, in thousands of kilometers above sea level, calculated using geospatial data at a 1-degree resolution from the Geographically based Economic data (G-ECON) project (Nordhaus, 2006), which is, in turn, based on similar data at a 10-minute resolution from New et al. (2002). The measure is aggregated up to the country level by averaging across the grid cells that are located within a country's national borders. See the $G$-ECON project website for additional details.

Variation in elevation. The standard deviation of elevation (as discussed above) across the grid cells (at a 1-degree resolution) that are located within a country's national borders. See the G-ECON project website for additional details.

Dispersion in elevation. The difference between the maximum and minimum values of elevation (as discussed above) across the grid cells (at a 1-degree resolution) that are located within a country's national borders. See the $G$-ECON project website for additional details.

Percentage of arable land. The fraction of a country's total land area that is arable, as reported for the year 2000 by the World Bank's World Development Indicators online.

Distance to waterways. The distance, in thousands of kilometers, from a geospatial grid cell to the nearest ice-free coastline or sea-navigable river, averaged across the grid cells that are located within a country's national borders. This variable, developed by Gallup, Sachs and Mellinger (1999), is available from the online Research Datasets repository maintained by Harvard University's Center for International Development.

Total land area. The total land area of a country, in millions of square kilometers, as reported for the year 2000 by the World Bank's World Development Indicators online.

Temperature. The average monthly temperature of a country, in units of ten degrees Celsius per month, over the 1961-1990 time period, calculated using geospatial data on average monthly 
temperature for this period at a 1-degree resolution from the G-ECON project (Nordhaus, 2006), which is, in turn, based on similar data at a 10-minute resolution from New et al. (2002). The measure is aggregated up to the country level by averaging across the grid cells that are located within a country's national borders. See the $G-E C O N$ project website for additional details.

Precipitation. The average monthly precipitation of a country, in units of ten millimeters per month, over the 1961-1990 time period, calculated using geospatial data on average monthly precipitation for this period at a 1-degree resolution from the G-ECON project (Nordhaus, 2006), which is, in turn, based on similar data at a 10-minute resolution from New et al. (2002). The measure is aggregated up to the country level by averaging across the grid cells that are located within a country's national borders. See the $G-E C O N$ project website for additional details.

Percentage of land in tropical and subtropical climate zones. The fraction of a country's total land area that is located in regions classified as tropical or subtropical by the Köppen-Geiger climate classification system. This variable, developed by Gallup, Sachs and Mellinger (1999), is available from the online Research Datasets repository maintained by Harvard University's Center for International Development.

Disease richness. The total number of different types of infectious diseases in a country, as reported by Fincher and Thornhill (2008), based on the Global Infectious Disease and Epidemiology Network (GIDEON) online database. See Fincher and Thornhill (2008) for additional details.

Island nation dummy. An indicator for whether or not a country shares a land border with any other country, as reported by the CIA's World Factbook online.

Landlocked dummy. An indicator for whether or not a country is landlocked, as reported by the CIA's World Factbook online. 


\section{B Supplementary Results}

TABle B.1: First-Stage Regressions

\begin{tabular}{|c|c|c|}
\hline & $\begin{array}{c}(1) \\
\text { OLS } \\
\text { First stage of } \\
\text { Columns } 2-6 \\
\end{array}$ & $\begin{array}{c}(2) \\
\text { OLS } \\
\text { First stage of } \\
\text { Columns 7-8 } \\
\end{array}$ \\
\hline Migratory distance from East Africa & $\begin{array}{c}-0.598^{* * *} \\
(0.084)\end{array}$ & $\begin{array}{c}-0.609^{* * *} \\
(0.094)\end{array}$ \\
\hline Years since Neolithic & $\begin{array}{c}0.066 \\
(0.096)\end{array}$ & $\begin{array}{c}0.109 \\
(0.101)\end{array}$ \\
\hline Settlement duration & $\begin{array}{c}0.122^{* *} \\
(0.053)\end{array}$ & $\begin{array}{c}0.070 \\
(0.061)\end{array}$ \\
\hline Duration as colony & $\begin{array}{l}-0.041 \\
(0.087)\end{array}$ & $\begin{array}{l}-0.036 \\
(0.088)\end{array}$ \\
\hline Absolute latitude & $\begin{array}{c}0.032 \\
(0.034)\end{array}$ & $\begin{array}{c}0.009 \\
(0.035)\end{array}$ \\
\hline Mean land quality & $\begin{array}{c}0.031 \\
(1.122)\end{array}$ & $\begin{array}{c}0.882 \\
(1.240)\end{array}$ \\
\hline Variation in land quality & $\begin{array}{l}-0.387 \\
(1.887)\end{array}$ & $\begin{array}{l}-1.036 \\
(1.876)\end{array}$ \\
\hline Mean elevation & $\begin{array}{c}0.670 \\
(0.519)\end{array}$ & $\begin{array}{c}0.371 \\
(0.647)\end{array}$ \\
\hline Variation in elevation & $\begin{array}{c}-4.092^{* *} \\
(1.661)\end{array}$ & $\begin{array}{c}-5.016^{* *} \\
(1.988)\end{array}$ \\
\hline Dispersion in elevation & $\begin{array}{l}0.658^{*} \\
(0.360)\end{array}$ & $\begin{array}{c}0.921^{* *} \\
(0.439)\end{array}$ \\
\hline Observations & 143 & 129 \\
\hline Adjusted $R^{2}$ & 0.77 & 0.78 \\
\hline F-test of excluded instrument & 50.24 & 41.84 \\
\hline
\end{tabular}

Notes: This table reports the results from the first-stage regressions associated with the 2SLS regressions in Columns 2-8 of Table 1 of the paper, where genetic diversity (adjusted for post-1500 migrations) is instrumented using migratory distance from East Africa. All regressions include controls for the percentage of arable land, distance to waterways, total land area, temperature, precipitation, the percentage of land in tropical and subtropical climate zones, disease richness, and island, landlocked, and continental fixed effects. Heteroskedasticity-robust standard errors are reported in parentheses. $* * *$ denotes statistical significance at the 1 percent level, ${ }^{* *}$ at the 5 percent level, and $*$ at the 10 percent level. 
TAble B.2: Genetic Diversity and Ethnolinguistic Heterogeneity across Countries in the Old World

\begin{tabular}{|c|c|c|c|c|c|c|c|}
\hline & $\begin{array}{c}(1) \\
\text { OLS } \\
\text { EG }\end{array}$ & $\begin{array}{c}(2) \\
\text { OLS } \\
\text { EF-F }\end{array}$ & $\begin{array}{c}(3) \\
\text { OLS } \\
\text { EF-A }\end{array}$ & $\begin{array}{c}\text { (4) } \\
\text { OLS } \\
\text { ELF-D }\end{array}$ & $\begin{array}{c}\text { (5) } \\
\text { OLS } \\
\text { POL-D }\end{array}$ & $\begin{array}{c}(6) \\
\text { OLS } \\
\text { POL-ER }\end{array}$ & $\begin{array}{c}(7) \\
\text { OLS } \\
\text { POL-RQ }\end{array}$ \\
\hline Genetic diversity & $\begin{array}{c}14.750^{* * *} \\
(4.317)\end{array}$ & $\begin{array}{c}6.867^{* * *} \\
(1.948)\end{array}$ & $\begin{array}{l}3.612^{*} \\
(1.940)\end{array}$ & $\begin{array}{c}3.881^{* *} \\
(1.550)\end{array}$ & $\begin{array}{c}6.886^{* *} \\
(2.663)\end{array}$ & $\begin{array}{c}1.120^{* *} \\
(0.486)\end{array}$ & $\begin{array}{c}1.137^{*} \\
(0.589)\end{array}$ \\
\hline Years since Neolithic & $\begin{array}{c}-0.071^{*} \\
(0.038)\end{array}$ & $\begin{array}{c}-0.022 \\
(0.019)\end{array}$ & $\begin{array}{c}-0.010 \\
(0.021)\end{array}$ & $\begin{array}{l}-0.018 \\
(0.015)\end{array}$ & $\begin{array}{c}-0.026 \\
(0.027)\end{array}$ & $\begin{array}{l}-0.007 \\
(0.005)\end{array}$ & $\begin{array}{c}-0.006 \\
(0.006)\end{array}$ \\
\hline Settlement duration & $\begin{array}{c}0.038 \\
(0.023)\end{array}$ & $\begin{array}{c}0.020 \\
(0.013)\end{array}$ & $\begin{array}{c}0.010 \\
(0.014)\end{array}$ & $\begin{array}{c}0.011 \\
(0.007)\end{array}$ & $\begin{array}{c}0.019 \\
(0.012)\end{array}$ & $\begin{array}{c}0.003 \\
(0.002)\end{array}$ & $\begin{array}{l}-0.000 \\
(0.004)\end{array}$ \\
\hline Duration as colony & $\begin{array}{c}0.019 \\
(0.024)\end{array}$ & $\begin{array}{c}0.018^{*} \\
(0.011)\end{array}$ & $\begin{array}{c}-0.004 \\
(0.013)\end{array}$ & $\begin{array}{c}0.015 \\
(0.010)\end{array}$ & $\begin{array}{l}0.030 * \\
(0.018)\end{array}$ & $\begin{array}{c}0.003 \\
(0.004)\end{array}$ & $\begin{array}{c}0.005 \\
(0.005)\end{array}$ \\
\hline Absolute latitude & $\begin{array}{c}-0.003 \\
(0.015)\end{array}$ & $\begin{array}{c}0.001 \\
(0.006)\end{array}$ & $\begin{array}{c}-0.003 \\
(0.006)\end{array}$ & $\begin{array}{c}0.005 \\
(0.005)\end{array}$ & $\begin{array}{c}0.010 \\
(0.009)\end{array}$ & $\begin{array}{c}0.003^{* *} \\
(0.001)\end{array}$ & $\begin{array}{c}0.003^{* *} \\
(0.001)\end{array}$ \\
\hline Mean land quality & $\begin{array}{c}-0.638^{* *} \\
(0.305)\end{array}$ & $\begin{array}{c}-0.239 \\
(0.158)\end{array}$ & $\begin{array}{c}-0.249^{*} \\
(0.147)\end{array}$ & $\begin{array}{c}-0.184^{* *} \\
(0.092)\end{array}$ & $\begin{array}{c}-0.322^{*} \\
(0.171)\end{array}$ & $\begin{array}{l}-0.011 \\
(0.027)\end{array}$ & $\begin{array}{l}-0.037 \\
(0.043)\end{array}$ \\
\hline Variation in land quality & $\begin{array}{l}1.015^{*} \\
(0.575)\end{array}$ & $\begin{array}{c}0.215 \\
(0.290)\end{array}$ & $\begin{array}{l}-0.128 \\
(0.293)\end{array}$ & $\begin{array}{l}-0.056 \\
(0.205)\end{array}$ & $\begin{array}{c}-0.093 \\
(0.373)\end{array}$ & $\begin{array}{l}-0.028 \\
(0.067)\end{array}$ & $\begin{array}{l}-0.007 \\
(0.100)\end{array}$ \\
\hline Mean elevation & $\begin{array}{c}-0.152 \\
(0.154)\end{array}$ & $\begin{array}{l}-0.085 \\
(0.079)\end{array}$ & $\begin{array}{l}-0.058 \\
(0.075)\end{array}$ & $\begin{array}{l}-0.019 \\
(0.062)\end{array}$ & $\begin{array}{l}-0.041 \\
(0.114)\end{array}$ & $\begin{array}{c}0.009 \\
(0.016)\end{array}$ & $\begin{array}{c}0.050 * * \\
(0.022)\end{array}$ \\
\hline Variation in elevation & $\begin{array}{l}-0.327 \\
(0.385)\end{array}$ & $\begin{array}{c}0.146 \\
(0.193)\end{array}$ & $\begin{array}{c}0.185 \\
(0.185)\end{array}$ & $\begin{array}{c}0.312^{*} \\
(0.162)\end{array}$ & $\begin{array}{c}0.575^{*} \\
(0.294)\end{array}$ & $\begin{array}{c}0.050 \\
(0.052)\end{array}$ & $\begin{array}{l}-0.004 \\
(0.059)\end{array}$ \\
\hline Dispersion in elevation & $\begin{array}{l}0.172^{*} \\
(0.090)\end{array}$ & $\begin{array}{c}0.026 \\
(0.046)\end{array}$ & $\begin{array}{c}0.019 \\
(0.044)\end{array}$ & $\begin{array}{c}-0.063^{*} \\
(0.037)\end{array}$ & $\begin{array}{c}-0.110^{*} \\
(0.066)\end{array}$ & $\begin{array}{l}-0.016 \\
(0.013)\end{array}$ & $\begin{array}{l}-0.010 \\
(0.014)\end{array}$ \\
\hline Observations & 118 & 118 & 118 & 118 & 118 & 106 & 106 \\
\hline Adjusted $R^{2}$ & 0.41 & 0.48 & 0.49 & 0.30 & 0.31 & 0.26 & 0.12 \\
\hline
\end{tabular}

Notes: This table demonstrates, exploiting variations across countries in the Old World, the statistically significant positive relationships between genetic diversity (adjusted for post-1500 migrations) and various measures of contemporary ethnolinguistic heterogeneity, conditional on geographical and historical covariates. All regressions include controls for the percentage of arable land, distance to waterways, total land area, temperature, precipitation, the percentage of land in tropical and subtropical climate zones, disease richness, and island, landlocked, and continental fixed effects. Heteroskedasticity-robust standard errors are reported in parentheses. *** denotes statistical significance at the 1 percent level, ${ }^{* *}$ at the 5 percent level, and ${ }^{*}$ at the 10 percent level. 


\section{References}

Ahlerup, Pelle, and Ola Olsson. 2012. "The Roots of Ethnic Diversity." Journal of Economic Growth, 17(2): 71-102.

Alesina, Alberto, and Eliana La Ferrara. 2005. "Ethnic Diversity and Economic Performance." Journal of Economic Literature, 43(3): 762-800.

Alesina, Alberto, Arnaud Devleeschauwer, William Easterly, Sergio Kurlat, and Romain Wacziarg. 2003. "Fractionalization." Journal of Economic Growth, 8(2): 155-194.

Ashraf, Quamrul, and Oded Galor. 2013. "The "Out of Africa" Hypothesis, Human Genetic Diversity, and Comparative Economic Development." American Economic Review, 103(1): 1-46.

Desmet, Klaus, Ignacio Ortuño-Ortín, and Romain Wacziarg. 2012. "The Political Economy of Linguistic Cleavages." Journal of Development Economics, 97(2): 322-338.

Duclos, Jean-Yves, Joan Esteban, and Debraj Ray. 2004. "Polarization: Concepts, Measurement, Estimation." Econometrica, 72(6): 1737-1772.

Esteban, Joan, and Debraj Ray. 2011. "Linking Conflict to Inequality and Polarization." American Economic Review, 101(4): 1345-1374.

Esteban, Joan, Laura Mayoral, and Debraj Ray. 2012. "Ethnicity and Conflict: An Empirical Study." American Economic Review, 102(4): 1310-1342.

Fearon, James D. 2003. "Ethnic and Cultural Diversity by Country." Journal of Economic Growth, 8(2): 195-222.

Fincher, Corey L., and Randy Thornhill. 2008. "Assortative Sociality, Limited Dispersal, Infectious Disease and the Genesis of the Global Pattern of Religion Diversity." Proceedings of the Royal Society B, 275(1651): 2587-2594.

Gallup, John Luke, Jeffrey D. Sachs, and Andrew D. Mellinger. 1999. "Geography and Economic Development." International Regional Science Review, 22(2): 179-232.

Michalopoulos, Stelios. 2012. "The Origins of Ethnolinguistic Diversity." American Economic Review, 102(4): 1508-1539.

Montalvo, José G., and Marta Reynal-Querol. 2005. "Ethnic Polarization, Potential Conflict, and Civil Wars." American Economic Review, 95(3): 796-816.

New, Mark, David Lister, Mike Hulme, and Ian Makin. 2002. "A High-Resolution Data Set of Surface Climate Over Global Land Areas." Climate Research, 21(1): 1-25.

Nordhaus, William D. 2006. "Geography and Macroeconomics: New Data and New Findings." Proceedings of the National Academy of Sciences, 103(10): 3510-3517. 
Putterman, Louis. 2008. "Agriculture, Diffusion, and Development: Ripple Effects of the Neolithic Revolution." Economica, 75(300): 729-748.

Putterman, Louis, and David N. Weil. 2010. "Post-1500 Population Flows and the Long Run Determinants of Economic Growth and Inequality." Quarterly Journal of Economics, 125(4): 1627-1682.

Ramachandran, Sohini, Omkar Deshpande, Charles C. Roseman, Noah A. Rosenberg, Marcus W. Feldman, and L. Luca Cavalli-Sforza. 2005. "Support from the Relationship of Genetic and Geographic Distance in Human Populations for a Serial Founder Effect Originating in Africa." Proceedings of the National Academy of Sciences, 102(44): 15942-15947.

Ramankutty, Navin, Jonathan A. Foley, John Norman, and Kevin McSweeney. 2002. "The Global Distribution of Cultivable Lands: Current Patterns and Sensitivity to Possible Climate Change." Global Ecology and Biogeography, 11(5): 377-392.

Reynal-Querol, Marta. 2002. "Ethnicity, Political Systems, and Civil Wars." Journal of Conflict Resolution, 46(1): 29-54.

Spolaore, Enrico, and Romain Wacziarg. forthcoming. "How Deep are the Roots of Economic Development?" Journal of Economic Literature. 